\title{
Effect of Bibliotherapeutic Approach on Problem-Solving Skills of Gifted/Talented Students
}

\begin{tabular}{ccc}
\hline Article Type & Received Date & Accepted Date \\
Research & 26.10 .2018 & 17.01 .2019 \\
\hline
\end{tabular}

\section{Hüseyin Taş**}

\begin{abstract}
This study determined the effect of children's literature texts addressed through bibliotherapy method on one of the superior thinking skills, the problem solving skill, of the gifted/talented students. Gifted/talented students show different development characteristics compared to their peers. This requires supporting those students and ensuring their improvement. This study aims to introduce the bibliotherapeutic approach, and to transform the children's literature texts selected taking into account the characteristics of gifted/talented students into a model, and to identify the effect of this model on the problem-solving skills of gifted/talented students. Among the quantitative research methods, the study used pretest-posttest uncontrolled semi-experimental model - since there was only one analysis group in the study. The study group consists of Science and Arts Center students diagnosed as gifted/talented. Since this research constitutes an experimental study, a study group was identified rather than a study population and sample. A problem-solving skill scale was used to evaluate the problem solving skills of gifted/talented students. The research findings showed that, in conclusion of the application, there occurred an increase in problem-solving skill levels of the gifted/talented children in the study group.
\end{abstract}

Keywords: Bibliotherapy, the gifted, the talented, problem-solving skill, education.

\footnotetext{
${ }^{* *} \mathrm{PhD}$ Student, Sakarya University, Institute of Educational Sciences, Sakarya, Turkey. E-mail: huseyintas2005@ hotmail.com, https://orcid.org/0000-0001-9873-5723
} 


\title{
Bibliyoterapi Yönteminin Üstün Zekâlı/Yetenekli Öğrencilerin Problem Çözme Becerisine Etkisi
}

\begin{tabular}{ccc}
\hline Makale Türü & Başvuru Tarihi & Kabul Tarihi \\
Araştırma & 26.10 .2018 & 17.01 .2019 \\
\hline
\end{tabular}

\section{Hüseyin Taş**}

\begin{abstract}
$\ddot{O} z$
Üstün zekâlı ve yetenekli öğrenciler yaşıtları ile karşılaştırıldıklarında farklı gelişim özellikleri gösterir. $\mathrm{Bu}$ durum onların desteklenmesini ve gelişmelerinin sağlanmasını gerekli kılar. $\mathrm{Bu}$ çalışmanın amacı bibliyoterapi yönteminin tanıtılması ve üstün zekâlı/yetenekli öğrencilerin özelliklerini de dikkate alarak seçilecek çocuk edebiyatı metinlerinin bu yöntem ile bir modele dönüştürülmesi ve bu modelin üstün zekâl1/yetenekli öğrencilerin problem çözme becerisi üzerindeki etkisini tespit etmektir. Araştırmada nicel araştırma yöntemlerinden -çalışmada tek analiz grubu yer aldığı için- ön test-son test kontrol grupsuz yarı deneysel model kullanılmıştır. Çalışma gurubu üstün zekâl1/yetenekli tanısı konulmuş Bilim ve Sanat Merkezi öğrencileridir. Bu araştırma deneysel bir çalışma olduğu için evren ve örneklem yerine çalışma grubu belirlenmiştir. Üstün zekâlı/yetenekli ögrencilerin problem çözme becerilerini ölçmek amaciyla problem çözme becerisi ölçeği kullanılmıştır. Araştırma bulgularına göre çalışma grubunda yer alan üstün zekâl1/yetenekli çocukların uygulama sonucunda problem çözme beceri düzeylerinde artış olduğu sonucuna ulaşılmıştır. Araştırma sonunda ortaya çıkan bu sonuçlar değerlendirildiğinde çalışma grubunda yer alan öğrencilerin üstün zekâlı/yetenekli olmaları ve özellikle okuma konusunda istekli olmalarının etkili olduğu söylenebilir. Ayrıca bu çocukların problem çözme ve muhakeme yeteneklerinin bu sonuçları olumlu yönde etkilediği düşünülmektedir.
\end{abstract}

Anahtar Sözcükler: Bibliyoterapi, üstün zekâlılar, üstün yetenekliler, problem çözme becerisi, eğitim.

\footnotetext{
*** Doktora Öğrencisi, Sakarya Üniversitesi Eğitim Bilimleri Enstitüsü, Sakarya, Türkiye.

E-posta: huseyintas2005@hotmail.com, https://orcid.org/0000-0001-9873-5723
} 


\section{Introduction}

Proceeding to training and learning from the moment of birth, the human being learns something at each phase of life. One of the most important experiences in human life is the period of learning how to read and write. Because, with reading and writing skill, man passes from foreign-dependent learning through ability to learn new things in line with his own wishes. Through Books, he learns what happened before him; and in this way, he gets acquainted with the mankind and begins to develop new values regarding life and reality.

According to the child, a book is a world of images which contains sketches, images and colors in itself and is compiled using creative narrative ways. One can say that, in this lively world, the child gets to know better the many individuals and personality traits of heroes in the work as well as all of their communication and relationships with the people around them. This constitutes an indirect life experience for the child (Öner, 2007, p. 133).

Literature is a set of oral and written productions that titivate individuals' feelings and ideas to words, bear a literary and artistic value and inhold no evil and banality. Children's literature, which allows for giving voice to one's feelings and opinions, however addresses the child's pleasures and dream world, and tries to contribute to their development in all aspects (Uçan, 2006, p. 76).

Children's literature is "the fullest extent of oral and written yields addressing children's dreams, feelings, thoughts, talents and tastes and contributing to their fun while training" (Yalçın and Aytaş, 2003, p. 17).

Children's literature is a set of verbal and written productions that are suitable for the bodily and mental development of individuals considered as children, are far from ugliness and vulgarity, and allow the child to understand, comprehend and interpret through listening and reading and to have fun in the educational process (Şimşek, 2005, p. 78).

Advising a child to read books that are suitable for his/her age and in line with his/her ability to understand is the most important factor that increases children's reading rates. It should be noted that, children in each age group have their own unique characteristics, and it can also be argued that these characteristics may vary even among boys and girls (Celkan, 2006, p. 615).

This effect of books in human life requires the combination of mother language courses with other disciplines, particularly the science of psychology. Despite being a subject of psychology, bibliotherapy is a matter that can be considered especially in the field of Turkish education in the process of setting individuals up with children's literature products.

Apparently posing a complex and assertive perception, 'Bibliotherapy' is indeed a word used for a situation that can be considered as a simple process. The fact that bibliotherapy contains the word "therapy" in itself should not suggest that this method is only a clinical approach relating to the field of psychology. It can be said that this approach allows for bringing the right person and the right book together at the right time and thus helps the individual feel comfortable spiritually and mentally (Philpot, 1997) (Ref., Öner, 2007, p. 136).

Besides providing guidance in solving personal problems through directed reading, bibliotherapy is also expressed as assigning such tasks as reading brochures, articles and books to the groups receiving a certain consulting service in order to eliminate false attitudes adopted by the individuals and to transform their weak motivation into a more robust one (McCulliss, 2012, p. 23). (Wolberg, 1967, p. 578).

Given its application areas, bibliotherapy is divided into two groups, namely clinical bibliotherapy and developmental bibliotherapy. Clinical bibliotherapy is performed by an expert and claims to treat individual serious, emotional/behavioral problems. Developmental bibliotherapy, however, is often used in educational institutions and accepts the reading process between the personality of the reader and literature as an interaction (Hebert and Furner, 1997).

Halsted (2002) suggests that one passed through four different stages in the process of bibliotherapy: 
Identification: In bibliotherapy, this is the stage where the relationship between the reader and the book heroes begins (Ilter, 2015, p. 40). If pre-reading conditions have been fulfilled at this stage, the reader would succeed in empathizing with the real or imaginary character in the book.

Catharsis (Purification): In its sense of "purification", catharsis is defined as cleansing, making the soul free from passions in the Turkish Dictionary of the Turkish Language Association. At this stage, the student is expected to relax by betraying his/her feelings.

Insight: Insight is defined as "the ability to understand one's own feelings, one's self" in the Turkish Dictionary of the Turkish Language Association. At this stage, one observes that the hero in the book solves its problems, and thus realizes that the problems are not permanent. In other words, the individual associates the individual's experience with his/her own experience (Leana-Taşçlar, 2012, p. 122).

Generalization: Some researchers address this stage along with the stage "insight". Nevertheless, Heath, Sheen, Leavy, Young and Money (2005) address it as the stage where the individual can put himself/herself in another's place and realizes that he/she is not the only one who experience that circumstance or problem and that it may happen to others as well (Heath et al., 2005).

The reason why bibliotherapy is effective on the individual is that the students betray certain feelings such as sharing the same feelings with the heroes having traits similar to them - called "identification"-, and thus gain new perspectives and find different and new methods of interaction with their friends and the adults as well. In this way, bibliotherapy shows the individuals the ways in which others are able to solve their problems, and guides the individual in finding new methods to solve their personal problems (Bulut, 2010, p. 19).

Pardeck (1993) sets forth that a good piece of literature readily offers individuals the models necessary to help them to deal with real-life problems. Through bibliotherapy, students would be more inclined to share what they understand, and to reflect their behaviors through a third person or a literary character, a cartoon hero at a safe distance.

"The gifted/talented students who exhibit different traits in many aspects compared to their peers is the group which would show the highest performance in the educational process thanks to their motivation as well as fast and permanent learning abilities. The superior intelligence, one of the major traits of those children, refers to the high-level capacity unveiled in any performance field (Sak, 2013, p. 500)."

Giftedness started to be considered as a scientific concept in 19th Century, and as of this stage, the most apparent sign of superior intelligence was introduced as intelligence tests that measure intelligence in the concept of intelligence. In studies identifying the giftedness through these tests, the gifted/talented are those whose level of intelligence consistently brings a score of 130 or more as a result of the analysis (Ersoy and Avc1, 2004, p. 196).

Gifted/talented students show different development characteristics compared to their peers. This requires supporting those students and ensuring their improvement. This study aims to introduce the bibliotherapeutic approach, and to transform the children's literature texts selected taking into account the qualities of gifted/talented individuals into a model, and to identify the effect of this model on the problem-solving skills of gifted/talented students.

Bibliotherapy is a method that can be applied to students who are interested in reading by bringing them together with literary works in order to allow them to understand their inner worlds. Thanks to bibliotherapy, students become aware of their personality traits as well as their areas of interest, and gain courage in being at peace with the weaker aspects of their personality. Besides the described gain, this method also positively affects the reading skill of the student.

Bibliotherapy can be used to help the gifted/talented who exhibit such traits as early reading, reading more compared to their peers and preferring to read different types of works, etc. to become aware of their personality traits and what distinguishes him/her from his/her peers, and to enable them to create solutions for the problems they face by identifying their experiences with the characters in the books. 


\section{Research Model}

\section{Method}

This study determined the effect of children's literature texts addressed through bibliotherapy method on one of the superior thinking skills, the problem solving skill, of the gifted/talented students.

Among the quantitative research methods, the study used pretest-posttest uncontrolled semiexperimental model - since there was only one analysis group in the study. The pre-test in the study aims to determine the current situation of the groups regarding the research subject before the experimental study. The post-test however intends to find out whether the application was effective or not. The fact that the design of the study involves a pre-test is important in terms of predicting the results of the experimental study. The findings of the experimental study are obtained through the post-test applied to the groups.

\section{Table 1}

Research Design

\begin{tabular}{|c|c|c|c|c|}
\hline GROUP & PRE-TEST & & APPLICATION & POST-TEST \\
\hline Experimental Group & $\begin{array}{l}\text { Problem-Solving } \\
\text { Assessment Scale } \\
\text { (Pre-Test) }\end{array}$ & Skill & $\begin{array}{l}\text { Applications by Children's } \\
\text { Literature Texts addressed } \\
\text { through Bibliotherapeutic } \\
\text { Approach }\end{array}$ & $\begin{array}{l}\text { Problem-Solving } \\
\text { Assessment Scale } \\
\text { (Post-Test) }\end{array}$ \\
\hline
\end{tabular}

\section{Study Group (Through Purposeful Sampling)}

The study group consists of Science and Arts Center Grade 6 students, involving 8 females and 4 males, who were diagnosed as gifted/talented. The students included in the study group participated voluntarily in the study without disrupting their on-going educational process, and the necessary consent was obtained from the families of the students using the family consent form. This research is an experimental study. Therefore, a study group was identified rather than a population and sample.

\section{Data Collection Tools}

The problem-solving skill scale developed by (Sezgin, 2011) was used to evaluate the problem solving skills of gifted/talented students. In the scale development process, the study group was composed of 262 students who were studying at four, five, six, seven and eighth grades of a private primary school in Izmir in the school year 2010-2011. Expert opinion was obtained for the structural validity of the scale, and the reliability coefficient KR 20 was calculated for its reliability. As a result of statistical calculations made using Excel and SPSS programs, the KR 20 internal consistency coefficient of the scale was found to be .76. Also, the scale's reliability coefficient in terms of consistency predicted using test-retest method was calculated. As a result of this operation, the correlation coefficient was calculated as .94. (Sezgin, 2011, p. 2).”

As a result of the factor analysis performed for structural validity of the scale, the scale was found to have a single-factor structure explaining $58.79 \%$ of the total variance for the whole scale.

\section{Data Collection and Analysis}

The application process of research was conducted in Science and Art Center where students diagnosed as gifted/talented using various scientific tests study in the spring semester of the school year 2016-2017 in Ankara. The application was completed in 10 weeks, including the application period of pre-test and post-test. Students attend to Science and Art Centers for at least 4 hours a week, outside the formal education school hours. The study was conducted within the 2-hour period when the students were present at the Science and Art Center, and continued uninterruptedly for 10 weeks. The application was carried out with 6th grade students who studied at the step called "Period 
Developing Individual Abilities" at the Science and Art Center. Within the research, activities were created with

"Sakız Sardunya", a work written by Elif Safak for children, taking the model created by LeanaTaşcilar (2012) as the basis in line with the principles of bibliotherapy. During the application process, first the activity "creating a Venn diagram about the main hero and other heroes through Venn Diagram Creating activity" was performed in the identification phase whereas the application was continued performing the activities "bag of questions that should not be asked", "reflecting on concepts", "allegory (if I were...)" in the catharsis stage and finally, the activities "I am saving the country ALFABESTAN (ALPHABETLAND)", "write a story about your name" and "my sharing with the grand tree" was performed in the insight and generalization stages.

\section{Findings}

\section{Findings from the Problem-Solving Skill Scale}

Before applying the activities prepared according to the bibliotherapy technique, the descriptive statistics of the pre-test was analyzed to determine the minimum, maximum and mean score of the study group for the pre-test applied to individuals participating in the study and the standard deviation thereof, and the data obtained was tabulated. The descriptive statistics of the pre-test are given in the Table 2 .

\section{Table 2}

Descriptive Statistics of the Pre-Test

\begin{tabular}{cccccc}
\hline & Number of Subjects (N) & Minimum & Maximum & Mean (X) & Std. Deviation (SD) \\
Pre-Test & 12 & 9 & 15 & 12 & 2 \\
\hline
\end{tabular}

As is seen in Table 2, the mean value of the scores obtained by the participants from the pre-test was found to be 12. Based on this, it was concluded that the problem solving skills of the students in the study group were at a "high" level. Also as is shown in the table, the facts that the lowest score of the pre-test is 9 and the highest score is 15 show that the lower limit is at a "low" level whereas the upper limit is at a "high" level.

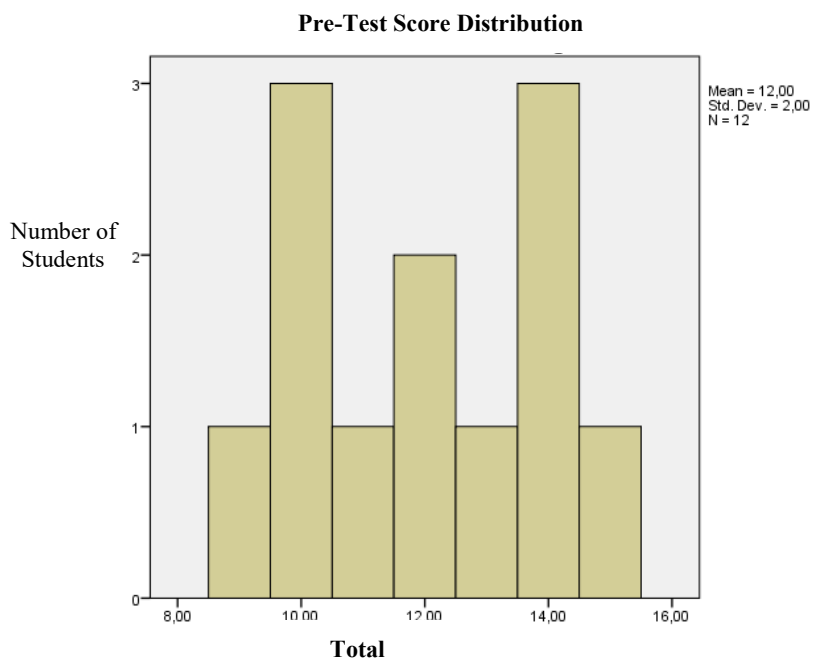

According to the pre-test score distribution chart, it is seen that the majority of the students in the study group obtained a score of 10 to 14 . The number of students who obtained a score of 14 to 16 , which was set as the highest level, is 4 according to the chart.

In order to find out the group's minimum, maximum and mean score for the post-test applied to students after the teaching process and the standard deviation thereof, the descriptive statistics of the 
post-test were examined and the data were tabulated. Table 3 presents the findings of the post-test results.

Table 3

Descriptive Statistics of the Post-Test

\begin{tabular}{lccccc}
\hline & Number of Subjects (N) & Minimum & Maximum & Mean (X) & Std. Deviation (SD) \\
\hline Post-Test & 12 & 10 & 16 & 13.75 & 1.65 \\
\hline
\end{tabular}

As is seen in Table 3, the average of the scores obtained by the students from the post-test is 13.75. It was thus concluded that the problem solving skills of the study group were high. The fact that the lowest score from the post-test is 10 indicates that the lower limit is at a "moderate" level, whereas the fact that the highest score is 16 shows that the upper limit is at the "highest" level.

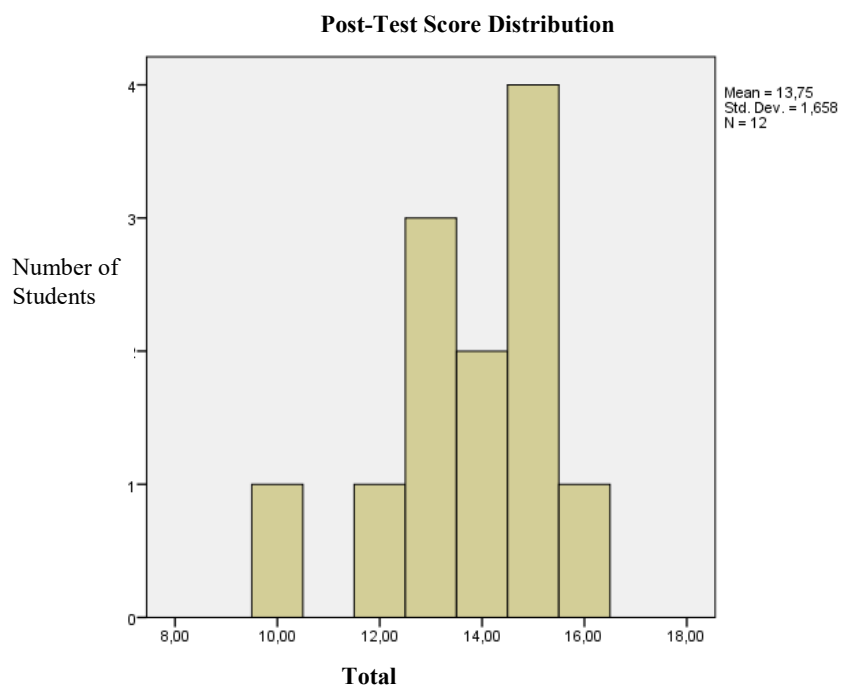

According to the post-test score distribution chart, it is seen that the majority of the students in the study group obtained a score of 12 to 16 . The number of students who obtained a score of 14 to 16 , which was set as the highest level, is 7 according to the chart.

In comparison of the data in the pre-test and post-test graphs, it was seen that the students' score from the post-test on their problem-solving skills showed an increase after the application. The scores obtained from the post-test are in the "high" and "highest" score ranges. Whereas the number of students who obtained a score of 14 to 16 , determined as the highest level, is 4 in the pre-test, this number increased to 7 in the post-test.

Comparing the data on Table 1 with those on Table 2, it is concluded that there occurred an increase in the minimum and maximum scores of the study group and the group's mean score for the problem solving skill showed an increase within the "high" level and approached to the "highest" level.

Following the analysis of pre- and post-tests relating to the Problem-Solving Skill Scale, the Wilcoxon Signed Rank Test was applied to the data in order to determine whether the difference between the pre-test and post-test is statistically significant. In cases where the number of subjects in groups is small (usually, when less than 30), nonparametric tests should be used. Because, as the number of subjects decreases, the probability of deterioration of assumptions in parametric tests increases (Sümbüloğlu and Sümbüloğlu, 2007, p. 52-53).

Table 4 shows the results obtained from the Wilcoxon Signed Rank Test. 


\section{Table 4}

Results from Wilcoxon Signed Rank Test applied to the Significance Level of the Difference between Pre-Test and Post-Test Scores within the Problem-Solving Ability Scale

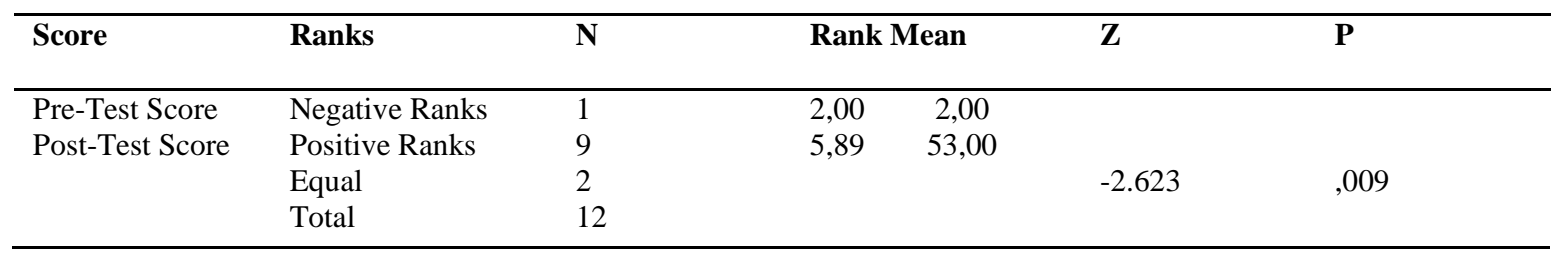

As can be understood from Table 4, the study group's scores from the pre-test applied prior to activities prepared with bibliotherapy technique was found to be significantly different $(p<0.05)$ from their scores obtained in post-test applied after the activities. $(Z=-2.623, p<0.05)$ This difference was in favor of the post-test. The problem-solving skills of the students in the study group showed a positive change.

\section{Discussion, Conclusion and Recommendations}

This study aims to introduce the bibliotherapeutic approach, and to transform the children's literature texts selected taking into account the characteristics of gifted/talented students into a model, and to identify the effect of this model on the problem-solving skills of gifted/talented students.

Within the study, certain activities were created based on the Elif Safak's work "Sakız Sardunya" containing a large majority of qualifications that a work to be used in bibliotherapy must contain and the model created by Leana-Taşcilar (2012). In this application model, the stages which students liked most were found to be the stages "Catharsis (Purification)" and "Insight", which rather involves discussing. A long period was assigned to the discussion, which is very important in bibliotherapy. The activities were designed in a way to feature questions to improve problem-solving and creativethinking skills (the activities "bag of questions that should not be asked", "reflecting on concepts"). At the end of these activities, the students learnt that they are not alone in facing problems, others also have the same problems, there are alternative solutions to the problems we encounter in life and they can feel relieved by realizing and thinking about this.

In the applied model, it was observed that the stage in which the students was bored most was the activities addressing predominantly the writing skills. Also, the students stated that it was more beneficial to read the book prior to attending the class rather than listening to it in the classroom. At the end of all activities, the application was thought to have reached the bibliotherapeutic objectives such as providing information, facilitating positive changes and personal development, encouraging discussion on problems and expressing new values and attitudes (Bryant and Roberts, 1992; Pardeck, 1995).

The research findings showed that, in conclusion of the application, there occurred an increase in problem-solving skill levels of the gifted/talented children in the study group. Comparing the pre-test and post-test statistical data, it is concluded that there occurred an increase in the minimum and maximum scores of the study group and the group's mean score for the problem solving skill showed an increase within the "high" level and approached to the "highest" level. This increase in problemsolving skills were observed not only in the total score but also a statistically significant difference was observed in favor of the post-test in the Wilcoxon Signed Rank Test.

As the results of the study are evaluated, the facts that the students in the study group are gifted/talented and they are disposed, especially to reading may have an effect on the results. Also, it is also thought that the results may be positively affected by the fact that those children have high problem-solving and reasoning skills (Clark, 2015). Besides, one can conclude that bibliotherapy can be used effectively with such a group.

This study contributed to the development of problem solving skills of the children by allowing them to discuss and produce a solution for their own problems through the similar problems 
experienced by a fictional hero, by means of this work used as the material of the study. Thus, the effect of bibliotherapy was increased.

In conclusion of this study, it was recognized that it is difficult to find books for bibliotherapy application in Turkey. Therefore, we think that the librarians should be trained in this respect. Book selection constitutes the basis for and the most difficult stage of bibliotherapy. It is also the most timesink and challenging part of the process. Although the foreign literature offers plenty of book recommendations for various problems and age groups after transferring information about bibliotherapy and even studies with examples for discussion and monitoring activities (Forgan and DeHass, 2004; Heath et al., 2005), the lack of those in the Turkish literature is the most prominent factor in making book selection difficult. It would be beneficial to use this technique, which is not only for therapy purposes but has a high preventive effect, as a preventive in classroom after providing a training for teachers in this regard. As a result of those findings, the bibliotherapy technique was found to affect positively the problem-solving skill in the gifted/talented sample. However, due to the limited number of study group, this study should also be applied to groups larger in number and higher age groups in order for generalizing it.

\section{References}

Bryant, J. \& Roberts, S. (1992). Bibliotherapy: an adjunct to audiologic counseling. JARA XXV, 5167.

Bulut, S. (2010). Bibliyoterapi yönteminin okullarda psikolojik danışmanlar ve öğretmenler tarafindan kullanılması. [Use of bibliotherapy method in schools by psychological counselors and teachers] Elektronik Sosyal Bilimler Dergisi, [Journal of Electronic Social Sciences] 9(34), 17-31.

Celkan, G. (2006). Çocuk edebiyatının dil eğitimi ve öğretimi açısından önemi. [The importance of children's literature in terms of language education and teaching] II. Ulusal Çocuk ve Gençlik Edebiyatı Sempozyumu Bildiri Kitabı, [II. National Children and Youth Literature Symposium Proceedings Book] S. 613-620. Ankara Üniversity.

Clark, B. (2015). Üstün zekalı olarak büyümek. evde ve okulda çocukların potansiyellerini gelisstirmek. [Growing up gifted. improve children's potential at home and at school] İstanbul: Nobel Academic Publishing.

Ersoy, Ö. \& Avcı, N. (2004). Özel eğitim [Special education] İstanbul: Ya-pa Publishing.

Forgan, J, \& DeHass, G. (2004). How to infuse social skills training into literacy instruction. Teaching Exceptional Children, 36(6), 24-37.

Halsted, J. W. (2002). Some of my best friends are books: Guilding gifted readers from preschool to high school. Scottsdale, AZ: Great Potential Press.

Heath, M. A., Sheen, D., Leavy, D., Young, E. \& Money, K. (2005). Biliotherapy: Aresource to facilitate emotional healing and growth. School Psychology, 26(5), 563-580.

Hebert, T. \& Furner, J. (1997). Helping high ability students overcome maths anxietythrough bibliotherapy. Journal of Secondary Gifted Education, 8(4), Sayfa 164-179.

İlter. B. (2015). Bibliyoterapi tekniğinin üstün yetenekli çocukların mükemmeliyetçiliği düzeylerine etkisi, [The effect of bibliotherapy technique on perfectionism levels of gifted children] (Unpublished Master Thesis), Fatih Sultan Mehmet Foundation University, Istanbul.

Leana- Taşcilar, M. (2012). Üstün zekâlı ve yetenekli öğrencilerin de bulunduğu sinıflarda bibliyoterapi kullanımı: model önerisi, [Use of bibliotherapy in classes with gifted and talented students: model proposal] Türk Üstün Zekâ ve Eğitim Dergisi, [Turkish Journal of Superior Intelligence and Education] 2(2), 118-136.

McCulliss, D. (2012). Bibliotherapy: Historical and research perspectives. Journal of Poetry Therapy, 25 (1): 23-38.

Öner, U. (2007). Bibliyoterapi, [Bibliotherapy] Journal of Arts and Sciences, Say1 7, Sayfa 133-150

Pardeck, J. T. (1993). Literature and adoptive children with disabilities. Early Child Development and Care, 91, 33-39.

Pardeck, J. T. (1995). Bibliotherapy: An innovative approach for helping children. Early Child Development and Care, 1 (1), 83-88.

Philpot, C. B. (1997). "Interactive story book software: effects on verbal development in kinder garten". Early Childhood Development and Care, 132, 33-44. 
Sak, U. (2013). Özel eğitime gereksinimi olan öğrenciler ve özel eğitim. [Special education students who require special education] Ankara: Pegem Academy.

Sezgin, E. (2011). Problem çözme becerisi ölçeğinin geliştirilmesi, [Developing the problem solving skill scale] (Unpublished Master Thesis) Ankara University Institute of Educational Sciences,

Sümbüloğlu, K. \& Sümbüloğlu, V. (2007). Biyoistatistik. [Biostatistics] Ankara: Hatiboğlu Printing and Publishing.

Uçan, H. (2006). Edebiyat eğitimi, estetik bir hazzın edinimi, okumanın alışkanlığa dönüştürülmesi ve yazınsal kuramlar. [Literature education, acquisition of aesthetic pleasure, transformation of reading into habit and literary theories] MEB Dergisi, [MEB Journal] 169, pp. 25-39.

Yalçın, A. \& Aytaş, G. (2003). Çocuk Edebiyatı. [Children's Literature] Ankara: Akçağ Publications.

Wolberg, L. R. (1967). "Hypnoanalysis." The technique of psychotherapy içinde (pp. 578-582). Vol 2. New York: Grune and Stratton. 